a two-shilling piece, and is as flat as those coins, these jelly-fishes are not referable to that species.

In life, they are almost hemispherical and slightly flattened on top; the largest do not measure more than I6 $\mathrm{mm}$. in their widest part, and the smallest measure about $6 \mathrm{~mm}$.

The Norquane is a narrow stream with a sandy bed cut into a succession of pools by granite bars. In all the pools over a distance of a mile, hundreds of the jelly-fishes were to be seen. The first specimen was found in a pool about $20 \mathrm{ft}$. by $30 \mathrm{ft}$. and $7 \mathrm{ft}$. deep, late in the afternoon, and a careful search did not at first reveal any more. Shortly after mu having a bathe in the same pool, numerous specimens came to the surface, and subsequent observation showed that the creatures swim near the surface in the earlier part of the day, and retire to the deeper water during the hotter hours, from which they were disturbed by the bathing. Their stinging powers, however feeble, probably render the jelly-fishes unpalatable to the fishes in the pool (chiefly Barbus 3-maculatus and Tilapia sp.), which left them severely alone.

I hope to be able soon to obtain Günther's paper in the Q.J.M.S. on Limnocnida tanganyikae, when it will be possible to decide whether or not this is a new and the fifth known species of fresh-water medusa. I should add that a careful examination of several pools during three days failed to reveal any signs of a hydrosome stage.

G. ARNOLD.

The Rhodesia Museum, Bulawayo, February 2 I.

\section{An Experiment for Showing Lines of Force in an Electrostatic Field.}

THE general directions of the lines of force between charged conductors can be shown by a method which, though extremely simple, shows as much as the elegant but somewhat elaborate apparatus described by Mr. R. F. D'Arcy (Nature, March 20) would seem capable of.

It is simply to allow a scrap of cotton-wool to fall between the knobs of a Wimshurst machine, or among any conductors connected with them. As soon as the bit of fluff touches one of the conductors it moves off rapidly along a line of force. If the other conductor is oppositely charged the fluff will strike it, and again be repelled, usually in a slightly different direction, thus traversing a different line of force, and so on.

The scrap of charged fluff moves so rapidly under the electric forces that, owing to the persistence of vision, the shape of its path is very evident, and, owing to its lightness and the relatively great resistance offered by the air to its motion, its path approximates very closely indeed to the line of force.

William Ellis School, London, N.W.

Bernard M. Neville.

\section{Snail-cavities in Stones.}

Referring to Mr. E. W. Swanton's letter in Nature of March 20, may I point out that the Agglestone rock is a sandstone composed of quartz grains bound together by a ferruginous cement.

I believe the excavations of Helix aspersa on rock surfaces are produced by chemical action, and that the secretion only acts as a solvent where salts of lime are present. This assumption seems reasonable on the supposition that the snails require lime for the construction of their shells.

Sandstones, unless calcareous, would have to be attacked mechanically by snails for cavities to be formed. Is there any evidence to prove that such cavities have been produced in sandstones?

\section{Carus-Wilson.}

\section{COMPLETION OF THE DISCOVERY OF} THE GREENLAND COASTS. ${ }^{1}$

THE last part of the coast of Greenland to remain undiscovered is the north-eastern tract between Germania Land and the area reached by Peary on his famous journey across the northern ice-sheet to Independence Fiord. This gap has been filled by the Danish expedition under Erichsen, which discovered that instead of the coast continuing in a fairly direct course from Germania Land in $77^{\circ} \mathrm{N}$. to Peary Land in $82 \frac{1}{2}$ N., Greenland projects in a long peninsula for $5^{\circ}$ to the east. The work of the supporting parties of this expedition made some interesting additions to the glacial geology of Greenland, which have been published in Koch and Wegener's memoir on the glacial observations. Erichsen's expedition achieved its object, but he and his two companions, Hagen and the Eskimo Brönlund, perished during the return journey. Brönlund was able to reach nearest home. His body and diary, with a map by Lieut. Hagen, were found by a search-party under Captain Koch. These papers announced the success of the expedition and its tragic end. The journals of Etichsen and Hagen were not recovered, and an expedition to search for them was dispatched under Captain Ejnar Mikkelsen in I9o9. This expedition was successful in recovering some messages left by Erichsen in his depôts, but it also nearly perished on the return journey.

The expedition sailed in a small sloop, the Alabama, but its plans were disorganised at the start. It called at the Faröe Islands to receive its dogs. But of the fifty dogs which had been bought in Greenland, twenty-three had died on the voyage to the Faröes, and the rest were so diseased that they had to be shot. The Alabama, therefore, had to go to the Eskimo settlements in south-eastern Greenland to buy dogs, and was thus seriously delayed. The expedition reached its base, Shannon Island (lat. $75^{\circ}$ ro ${ }^{\prime}$ N.), on August 27 , and a party in the autumn sledged up the eastern coast as far as Lambert's Land $\left(79^{\circ}\right)$, where they found Brönlund's grave. After wintering on Shannon Island, Captain Mikkelsen and Lieutenant Iversen marched across the inland ice to the head of Denmarks Fiord, which had betis discovered by Erichsen; they searched its coasts, found the site of Erichsen's camps, and recovered the messages left in them. Mikkelsen had intended to return to the Eskimo settlements on the western coast through the strait which, according to Peary, extends across northern Greenland; but this plan had to be abandoned when it was found from one of Erichsen's notes that "the Peary channel does not exist, Navy Cliff being connected by land with Heilprin Land." The author has commented severely on this mistake, but, considering the sufferings it caused him, his annoyance is intelligible.

1 "Lost in the Arctic." Being the Story of the Alabama Expedition, 1909-12. By Ejnar Mikkelsen. Pp. xviit+40o+plates. (London: W Heinemann, 1913.) Price 18s. net.

NO. 2266, VOL. 91] 